\title{
FOUR NEW SPECIES OF THE GENUS PTERICHIS (ORCHIDACEAE) FROM COLOMBIA
}

\author{
Marta KolanowsKa ${ }^{1} \&$ Dariusz L. SzlachetKo
}

\begin{abstract}
Four new species of the orchid genus Pterichis Lindl. are described and illustrated based on the Colombian material: P. andreii Kolan. \& Szlach., P. lehmanniana Kolan. \& Szlach., P. sagittata Kolan. \& Szlach. and P. Triangularilabia Kolan. $\&$ Szlach. Their taxonomic affinities are briefly discussed. All new entities are placed within a key to identification of the Colombian species of Pterichis.
\end{abstract}

Key words: biodiversity, Colombia, Cranichidinae, Neotropics, Pterichis, taxonomy

Marta Kolanowska \& Dariusz L. Szlachetko, Department of Plant Taxonomy and Nature Conservation, University of Gdańsk, ul. Wita Stwosza 59,80-308 Gdańsk, Poland; e-mail: martakolanowska@wp.pl

\section{INTRODUCTION}

While the systematic position of the vast majority of Orchidaceae has been discussed for many years, and while incoming data from molecular research has prompted researchers to amend the taxonomic position of many orchid genera, the generic separateness of Pterichis Lindl. as a member of Cranichideae has been questioned only by González Tamayo (1996).

The genus was described by John Lindley over 170 years ago (Lindley 1840). Currently ca 20 species are included in Pterichis (Cribb 2003). The plants are characterized by the presence of tuberous roots, rosulate leaves and a loosely sheathed scape. The leaves are often absent during anthesis. The flowers are nonresupinate, arranged in a usually loose raceme. Both the floral bracts and ovaries are densely ciliate or pubescent. The sessile, concave lip usually is ornamented with a series of knob-like projections along the margins.

Species of Pterichis grow terrestrially in paramo, but their occurrence has also been reported from high montane forest. The altitudinal amplitude of the genus extends from 2600 up to ca $4000 \mathrm{~m}$ a.s.1. Most of the species are found

\footnotetext{
1 Corresponding author
}

along the Andes from Bolivia to Colombia and Venezuela, but a few records come from Costa Rica and Jamaica (Cribb 2003; Dueńas Gómez \& Fernández Alonso 2009).

About half of the known Pterichis representatives occur in Colombia (Morales 1986; Ortiz Valdivieso \& Uribe Veléz 2007; Dueńas Gómez \& Fernández Alonso 2009). The novelties within a genus are rarely described because the collections from high Andean areas are insufficient and the morphological characters of Pterichis make it difficult to study from dried specimens (e.g., usually concave lip, frequent lack of leaves in preserved flowering plants).

Recent studies of Neotropical Cranichideae revealed the existence of four new species in the Colombian flora. They are described and illustrated in this paper. The taxonomic affinities of the new entities are presented and a key for identification of Colombian representatives of Pterichis is presented.

\section{DESCRIPTIONS OF THE NEW SPECIES}

Pterichis andreii Kolan. \& Szlach., sp. nov.

Fig. 1.

Species similar to P. parviflora (Lindl.) Schltr., distinguished by a long dorsal sepal, glabrous, 
obliquely oblong-ovate petals, 1-veined lateral sepals, the lip apex being longer than wide, with glandular ciliae only in the central part, and basal lip margins slightly enlarged, forming shapes resembling obtuse auricles.

Holotype: COLOMBIA, Cauca?, 14 Apr. 1876, André 2717 (K).

Plants over $18 \mathrm{~cm}$ tall, basal part absent in holotype. Leaf absent in holotype. Scape glandular, enclosed by at least 3 tubular, acute glandular sheaths. Inflorescence glandular-ciliate, 5-6 cm long, laxly few-flowered. Floral bracts glandularciliate, 6-8 $\mathrm{mm}$ long, subequal in length to ovary, ovate-lanceolate, acute. Ovary glandular-ciliate, 8-10 mm long. Flowers whitish, sepals externally glandular-ciliate, densely at base, sparsely above. Dorsal sepal $7.5 \mathrm{~mm}$ long, $3 \mathrm{~mm}$ wide, lanceolateovate, obtuse, 3-veined. Lateral sepals concave at base, $7.1 \mathrm{~mm}$ long, $2.7 \mathrm{~mm}$ wide, oblong-ovate, obtuse, 1-2-veined. Petals adnate to dorsal sepal, $6.8 \mathrm{~mm}$ long, $2.9 \mathrm{~mm}$ wide, obliquely oblong-
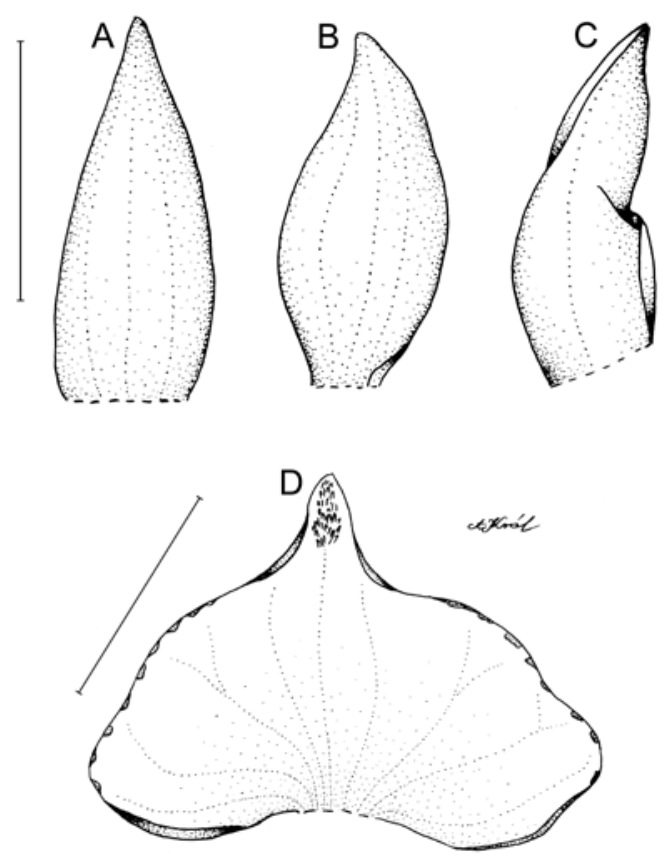

Fig. 1. Pterichis andreii Kolan. \& Szlach., sp. nov. A - dorsal sepal, B - petal, C - lateral sepal, D - lip. Scale bars $=5 \mathrm{~mm}$. Drawn by A. Król from the holotype. ovate, obtuse, 3-veined. Lip concave-cucullate, $5.5 \mathrm{~mm}$ long, $8 \mathrm{~mm}$ wide, transversely elliptictriangular in outline, basal part reniform, apex oblong-ovate, papillate in center; disc 9-veined, 3 middle veins thickened, lateral veins branching, margins ornamented with irregular knob-like projections. Gynostemium ca $2.5 \mathrm{~mm}$ long.

ETyMOLOGY. Dedicated to Edouard François André (1840-1911), the collector of the type specimen.

DISTRIBUTION: Known only from the type locality.

Notes. Similar to $P$. parviflora but with the dorsal sepal longer than the petals (vs. petals longer than dorsal sepal), glabrous, obliquely oblong-ovate petals (vs. petals narrowly oblong, ciliate on margins) and 1-veined lateral sepals (vs. lateral sepals 3- or 5-veined). While the lip apex of $P$. parviflora is more or less equally long and wide, papillate on the whole upper surface, the apex of $P$. andreii is longer than wide, with glandular ciliae only in the central part. The basal lip margins of $P$. andreii are slightly enlarged, forming shapes resembling obtuse auricles, which are not observed in P. parviflora. Another similar species is $P$. silvestris Schltr., but petal shape (obliquely oblong-ovate vs. ligulate or linear-ligulate) easily distinguishes those species.

Pterichis lehmanniana Kolan. \& Szlach., sp. nov.

Fig. 2

Species similar to P. mandonii Rchb. fil., distinguished by the long middle lobe of the lip, the lateral sepal shorter than the dorsal sepal and petals, and 3 -veined petals.

HoLOTYPE: [COLOMBIA]. Lehmann 1234 (K).

Plant over $12.5 \mathrm{~cm}$ tall, lower part absent in holotype. Leaves absent in holotype. Scape glandular, enclosed by 2 tubular sheaths. Inflorescence glandular-ciliate, $9 \mathrm{~cm}$ long, subdensely manyflowered. Floral bracts glandular-ciliate, up to 10 $\mathrm{mm}$ ovate, acute. Ovary glandular-ciliate, up to $10 \mathrm{~mm}$. Sepals externally glandular-ciliate. Dorsal sepal $10.5 \mathrm{~mm}$ long, $3 \mathrm{~mm}$ wide, lanceolate, ob- 

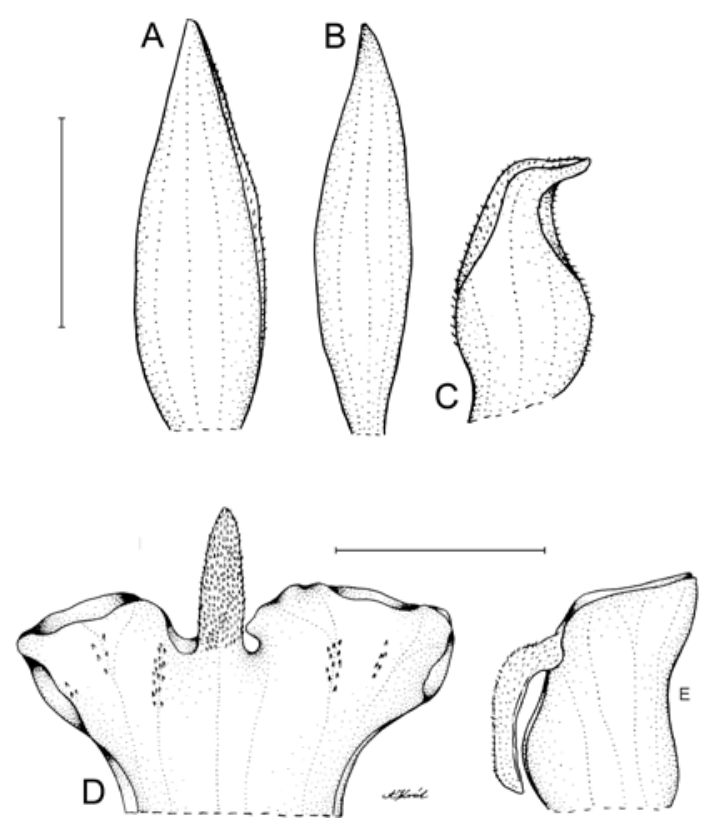

Fig. 2. Pterichis lehmanniana Kolan. \& Szlach., sp. nov. A dorsal sepal, B - petal, C - lateral sepal, D - lip, E - lip (side view). Scale bars $=5 \mathrm{~mm}$. Drawn by A. Król from the holotype.

tuse, 3-veined. Lateral sepals $7.5 \mathrm{~mm}$ long, $2.2 \mathrm{~mm}$ wide, ovate-lanceolate, obtuse, 3-veined. Petals adnate to dorsal sepal, glabrous, $10.5 \mathrm{~mm}$ long, $2.2 \mathrm{~mm}$ wide, linear-elliptic, subobtuse, 3-veined. Lip concave-conduplicate, $7 \mathrm{~mm}$ long, $9 \mathrm{~mm}$ wide, 3-lobed; middle lobe papillate, $3.2 \mathrm{~mm}$ long, 1 $\mathrm{mm}$ wide, oblong-lanceolate, obtuse, recurved in natural position; lateral lobes $5.3 \mathrm{~mm}$ long, $4.2 \mathrm{~mm}$ wide, obliquely subrhombic, margins incurved; disc 7-veined, sparsely and irregularly glandularciliate along apical part of veins. Gynostemium ca $3 \mathrm{~mm}$ long.

ETymology. Dedicated to Friedrich Carl Lehmann (1850-1903), the collector of the type specimen.

DISTRIBUTION: Known only from the type locality.

Notes. Species similar to P. mandonii but the lip middle lobe is much longer (3.2 vs. $1.5 \mathrm{~mm}$ long), the disc is ornamented only with somewhat thickened veins (vs. disc with knob-like projec- tions), the lateral sepals are shorter than the dorsal sepal and petals (vs. all tepals subequal in length), and the petals are 3-veined (vs. 1-veined).

The holotype was originally labelled 'Herbarium Lehmannianum Colombianum' but the last word of this name is pencilled-out and 'Chimbo Puente?' is hand-written above the label. The Ecuadorian Puente Chimbo is located at ca 200-300 m a.s.1., far below the altitudinal range of Pterichis species. As Lehmann's next plant (\#1235) was collected in Colombia (Páramo de Guanacas) we believe that the specimen that serves as the holotype of P. lehmanniana was also growing there.

Pterichis sagittata Kolan. \& Szlach., sp. nov.

Fig. 3

Species similar to $P$. galeata Lindl. and $P$. acuminata Schltr., distinguished by the sagittate lip with an almost glabrous disc, and the elongate, oblong-lanceolate lip apex ornamented with glandular ciliae only along its central part.

Holotype: COLOMBIA, Santa Rosa, Alt. 20002500 m, Mar 1891, Lehmann 1241 (K).

Plant ca $60 \mathrm{~cm}$ tall, basal part absent in holotype. Leaf absent in holotype. Scape glandular in upper half, enclosed by 5 tubular, acute sheaths, the upper ones glandular. Inflorescence glandularciliate, ca $11 \mathrm{~cm}$ long, laxly several-flowered. Floral bracts glandular-ciliate, ca $15 \mathrm{~mm}$ long, lanceolate, acute. Ovary glandular-ciliate, $c a$ $15 \mathrm{~mm}$ long. Sepals externally ciliate densely in basal part, sparsely above. Dorsal sepal $7 \mathrm{~mm}$ long, $2.3 \mathrm{~mm}$ wide, oblong-ovate, obtuse, 3-veined. Lateral sepals $7.5 \mathrm{~mm}$ long, $2.3 \mathrm{~mm}$ wide, obliquely ovate, obtuse, 3-veined. Petals free from dorsal sepal, glabrous, $8 \mathrm{~mm}$ long, $2.3 \mathrm{~mm}$ wide, obliquely oblong-elliptic, subacute, 3-veined. Lip concave-cucullate, $6 \mathrm{~mm}$ long, $7 \mathrm{~mm}$ wide, triangular-cordate in outline, somewhat sagittate, basal part somewhat crescent-like, apex oblonglanceolate, obtuse, densely glandular ciliate along apical part; disc 11-veined, lateral veins branching, ornamented with patch of ciliae in upper part of middle vein and with irregular knob-like projections on margins of basal part. Gynostemium $c a$ $2.5 \mathrm{~mm}$ long. 

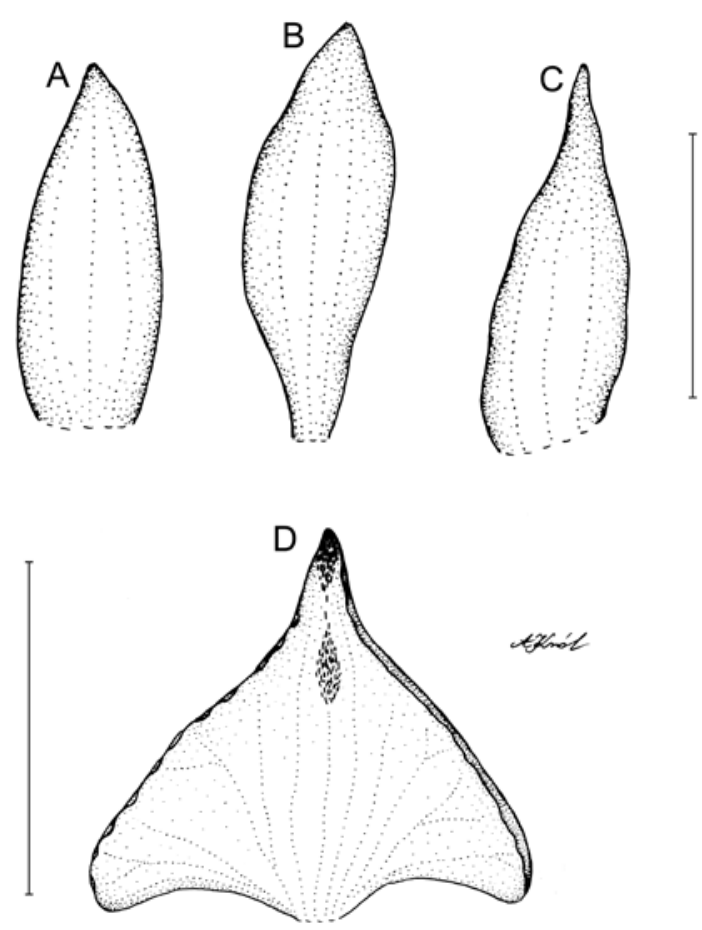

Fig. 3. Pterichis sagittata Kolan. \& Szlach., sp. nov. A - dorsal sepal, B - petal, C - lateral sepal, D - lip. Scale bars $=5 \mathrm{~mm}$. Drawn by A. Król from the holotype.

ETYMOLOGY. In reference to the lip shape.

DISTRIBUTION: Known only from the type locality.

Notes. Species resembling $P$. galeata and $P$. acuminata, from which it differs by the sagittate lip with a long oblong-lanceolate lip apex (vs. apex triangular or triangular-lanceolate) which is ornamented with glandular ciliae only along its central part (vs. apex papillate on whole upper surface) and almost glabrous disc (vs. disc puberulent).

Pterichis triangularilabia Kolan. \& Szlach., sp. nov.

Fig. 4

Species similar to $P$. galeata Lindl. and $P$. acuminata Schltr., distinguished by the short, densely flowered raceme, glandular-ciliate, oblong, 2-veined petals and triangular lip.
Holotype: COLOMBIA, Dept. CundinAmarca, Mun. Choachi. Páramo de Choachi, 18 Aug. 2007, J. Farfan, E. Buitrago \& D. Amaral 1074 (FMB).

Plant over $26 \mathrm{~cm}$ tall, lower part absent in holotype. Leaf absent in holotype. Scape glabrous near base, glandular above, enclosed by 5 tubular sheaths, upper ones glandular. Inflorescence glandular-ciliate, $c a 4.5 \mathrm{~cm}$ long, densely several-flowered. Floral bracts glandular-ciliate, ca $11 \mathrm{~mm}$ long, ovate, acute. Ovary glandularciliate, $c a 12 \mathrm{~mm}$ long. Flowers yellow with dark violet spots, sepals externally glandular-ciliate. Dorsal sepal $6 \mathrm{~mm}$ long, $2.7 \mathrm{~mm}$ wide, oblongovate, obtuse, minutely apiculate, 3-veined. Lateral sepals $6.2 \mathrm{~mm}$ long, $2.2 \mathrm{~mm}$ wide, ovate, obtuse, 3 -veined. Petals adnate to dorsal sepal, glandularciliate along margins, $6.5 \mathrm{~mm}$ long, $1.7 \mathrm{~mm}$ wide, oblong, somewhat oblique in apical part, subacute, 3-veined. Lip deeply concave at base, cucullate,
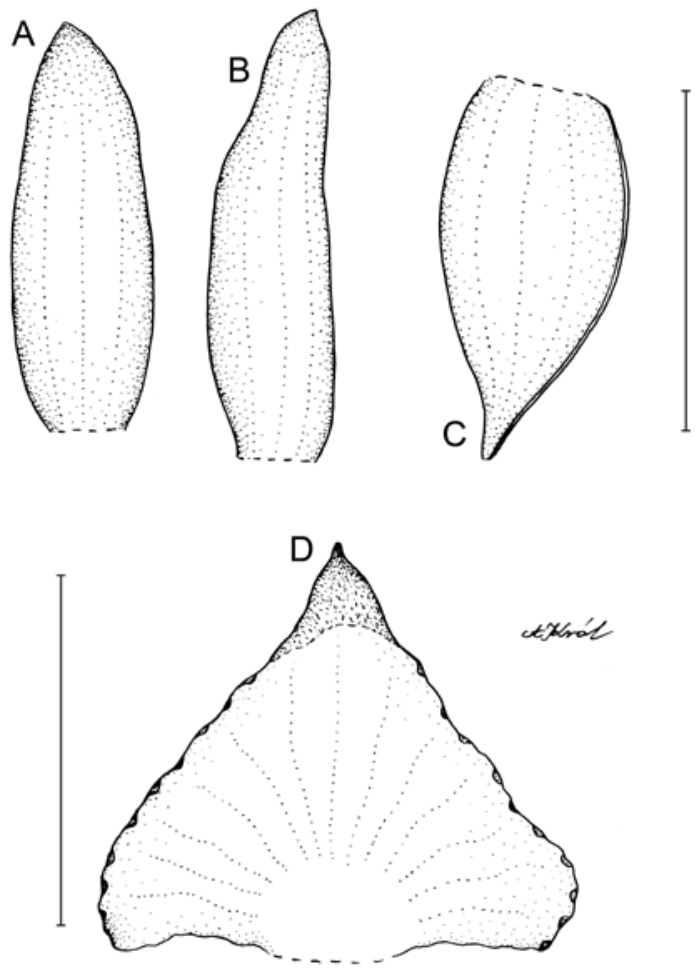

Fig. 4. Pterichis triangularilabia Kolan. \& Szlach., sp. nov. A - dorsal sepal, B - petal, C - lateral sepal, D - lip. Scale bar $=5 \mathrm{~mm}$. Drawn by A. Król from the holotype. 
$6 \mathrm{~mm}$ long, $7 \mathrm{~mm}$ wide, triangular, apex shortly apiculate, obtuse; disc 10-12-veined, veins not branching, margins ornamented with irregular knob-like projections; apical part of lip papillate. Gynostemium 2.5-3.0 mm long.

ETYMOLOGY. In reference to the lip shape.

HABITAT: Open paramo, among Calamagrostis.

DISTRIBUTION: Known only from the type locality.

Notes: This species resembles $P$. habenarioides (F. Lehm. \& Kraenzl.) Schltr., from which it differs by the lip form (triangular vs transversely triangular-elliptic) with a shortly apiculate, obtuse apex (vs. apex triangular to ligulate, obtuse, prominent) and almost glabrous disc (vs. disc minutely papillose). In its floral characters the new species is similar to $P$. galeata and $P$. acuminata, but differs from them by having petals adnate to the dorsal sepal, and glandular-ciliate, oblong petals (vs. petals glabrous, obliquely oblong-ovate). The inflorescences of both $P$. galeata and $P$. acuminata are usually much longer (up to $c a 30 \mathrm{~cm}$ ), sublaxly or loosely flowered (vs. inflorescence $4.5 \mathrm{~cm}$ long, densely flowered). In lip form P. triangularilabia somewhat resembles $P$. pauciflora, but the petals of the latter species are 2-veined (vs. petals 3-veined).

\section{Key to THE COLOMBIAN SPECIES OF PTERICHIS}

1. Petals free from dorsal sepal. . . . . . . . . . 2

1. Petals adnate to dorsal sepal ........... 4

2. Lip with long, oblong-lanceolate apex ....... ..................... P. sagittata

2 . Lip with triangular or triangular-lanceolate apex

3. Petals obliquely lanceolate-elliptic, unguiculate or narrowed below, lip with pair of auricles at edges of basal part ............... galeata

3. Petals obliquely oblong-lanceolate to lanceolatesagittate, basal lip auricles absent .. P. acuminata

4. Lip distinctly 3-lobed, apices of lateral lobes extend above base of middle lobe ........ 5

4. Lip indistinctly 3-lobed, elliptic-triangular to triangular or cordate in outline, lateral lobes gradually terminate in triangular to ligulate apex ..... 7
5. Lip without knob-like projections on margins, middle lobe over $3 \mathrm{~mm}$ long ........ P. lehmanniana

5. Lip with knob-like projections on margins, middle lobe $1.5 \mathrm{~mm}$ long ................. 6

6. Petals linear-lanceolate to narrowly lanceolate, 1 -veined .............. P. mandonii 6. Petals linear-oblong, 3-veined ......P. triloba

7. Petals glabrous $\ldots \ldots \ldots \ldots \ldots \ldots \ldots \ldots$

7. Petals externally glandular-pilose $\ldots \ldots \ldots \ldots 11$

8. Petals spathulate, sepals glabrous $\boldsymbol{P}$. fernandezii

8. Petals not spathulate, sepals externally glandularpilose ...................... 9

9. Scape densely brown-glandular-tomentose ...... $\ldots \ldots \ldots \ldots \ldots \ldots \ldots$ P. tomentosula

9. Scape glabrous below, densely glandular-puberulent above ...................... 10

10. Petals obliquely ligulate .......P. silvestris

10. Petals obliquely oblong-ovate ....P. andreii

11. Floral bracts elliptic ......... P. colombiana

$11^{*}$. Floral bracts ovate-lanceolate . . . . . . . . . 12 12. Sepals glabrous ..........P. parvifolia 12*. Sepals glandular-pubescent . . . . . . . . 13

13. Petals 3 -veined ................. 14

13. Petals 2-veined ............. P. pauciflora

14. Petals 3-4 times longer than wide ..... 15 14. Petals 5-6 times longer than wide ......... $\ldots \ldots \ldots \ldots \ldots \ldots \ldots$ P. multiflora

15. Lip triangular, apex shortly apiculate, obtuse .... $\ldots \ldots \ldots \ldots \ldots \ldots$ P. triangularilabia

15. Lip transversely triangular-elliptic, terminating in triangular to ligulate apex ..............

\section{P. habenarioides}

ACKNOWLEDGEMENTS. The Curator and staff of Royal Botanic Gardens, Kew are thanked for their kind hospitality and assistance during visits. We are grateful to Anna Król for preparing the illustrations and to the anonymous reviewers for valuable remarks on the manuscript. The research described was supported by a SYNTHESYS grant (GB-TAF-2445).

\section{REFERENCES}

Cribi P. 2003. Pterichis. In: A. M. Pridgeon, P. J. CribB, M. W. Chase \& F. N. RASMUSSEN (eds), Genera Orchidacearum. 3: 53-56. Oxford University Press, Oxford.

DueńAs Gómez H. C. \& FernÁndez Alonso J. L. 2009. Sinopsis de la Subfamilia Spiranthoideae (Orchidaceae) 
en Colombia, Parte II. Revista Acad. Colomb. Ci. Exact. 33: $157-181$.

GonZÁLEZ TAMAYO R. 1996. Nezahualcoyotlia (Cranichidinae, Orchidaceae), nuevo género del occidente de México. Bol. Inst. Bot. Univ. Guadalajara 4: 65-71.

LinDLEY J. 1840. The Genera and Species of Orchidaceous Plants. Ridgeway, London.
Morales G. 1986. El Genero Pterichis en Colombia. Orquideología 16: 53-79.

Ortiz Valdivieso P. \& URiBe VelÉz. C. 2007. Galería de Orquídeas de Colombia (CD edition). Asociación Bogotana de Orquideología, Bogotá.

Received 9 April 2013 